Revista peruana de biología 26(4): 405-409 (2019) doi: http://dx.doi.org/10.15381/rpb.v26i4.17212 ISSN-L 1561-0837; eISSN: 1727-9933

Universidad Nacional Mayor de San Marcos

\section{Two new species of the genus Stenommatus Wollaston, 1873 (Coleoptera: Curculionidae: Dryophthorinae; Dryophthorini) from Peru}

\section{TRABAJOS ORIGINALES}

$\begin{array}{ll}\text { Presentado: } & 04 / 05 / 2019 \\ \text { Aceptado: } & 23 / 07 / 2019 \\ \text { Publicado online: } & 16 / 12 / 2019\end{array}$

Correspondencia:

Andrei Legalov: fossilweevils@gmail.com

Otros datos de los autores / biografía: https://orcid.org/0000-0001-7347-8169

\section{Dos nuevas especies del género Stenommatus Wollaston, 1873 (Coleoptera: Curculionidae: Dryophthorinae; Dryophthorini) del Perú}

Citación:

Legalov A.A. 2019. Two new species of the genus Stenommatus Wollaston, 1873 (Coleoptera: Curculionidae: Dryophthorinae; Dryophthorini) from Peru. Revista peruana de biología 26(4): 405 - 409 (Diciembre 2019). doi: http://dx.doi.org/10.15381/ rpb.v26i4.17212

Palabras clave: Curculionoidea; taxonomía, biodiversidad sudamericana; escarabajos; gorgojos; clave.

Keywords: Curculionoidea; taxonomy, South American biodiversity; beetles; weevils; key.

\begin{abstract}
The weevil tribe Dryophthorini is reported in Peru for the first time. Two species from Satipo, Junin, Stenommatus chabooae Legalov n. sp. and Stenommatus sokolovi Legalov n. sp., are herein described. Stenommatus chabooae Legalov n. sp. is characterized by having the elytral interstriae narrower than striae width; pronotum coarsely punctate; large, narrow aedeagus, weakly curved at apex, with a large basal sclerite of the endophallus. Stenommatus sokolovi is characterized by having the elytral interstriae as wide as striae width; pronotum finely punctate; small, wide aedeagus, rounded at apex and endophallus lacking sclerites. A key to the South American species of the genus Stenommatus is given.

\section{Resumen}

Se reporta por primera vez la tribu Dryophthorini para Perú. Se describen dos especies de Satipo, Junín, Stenommatus chabooae Legalov n. sp. y Stenommatus sokolovi Legalov n. sp. Stenommatus chabooae Legalov n. sp. se caracteriza por poseer las interestrías elitrales más anchas que el ancho de las estrías; pronoto fuertemente punteado; aedeago grande, estrecho, ligeramente curvado en el ápice y con un esclerito basal grande en el endófalo. Stenommatus sokolovi n. sp. se caracteriza por poseer las interestrías elitrales tan anchas como el ancho de las estrías; pronoto finamente punteado y aedeago pequeño, ancho, redondeado en su ápice y endofalo sin escleritos. Se propone una clave para las especies sudamericanas del género Stenommatus.
\end{abstract}

Publicación registrada en Zoobank/ZooBank article registered:

LSIDurn:|sid:zoobank.org:pub:39DA5A87-2946-4026-9A49-ECFB2F04998C

Acto nomenclatural/nomenclatural act:

Stenommatus chabooae Legalov, 2019

LSIDurn:Isid:zoobank.org:act:C6B8C2E8-F448-4F33-8622-71D6A909D2AF

Stenommatus sokolovi Legalov, 2019

LSIDurn:Isid:zoobank.org:act:A50C26F3-8C19-44A8-A219-6516FF0564FA 


\section{Introduction}

The fauna of the family Curculionidae (weevils) is poorly studied in Peru. The main study is a review describing 65 new species (Voss 1954). There are some descriptions of species from Peru (Erichson 1847; Kirsch 1874; Hustache 1929; Howden 2001; etc.). General information about the weevil species of Peru is provided by Wibmer and O'Brien (1986). The beetle fauna of Peru is actively being studied in Caroline Chaboo's Beetles of Peru' project (see Chaboo 2015 and subsequent contributions); however, weevils remain an outstanding large family needing attention.

The subfamily Dryophthorinae is widespread in tropical and subtropical areas (Anderson and Marvaldi 2014). The tribe Dryophthorini is distributed almost everywhere (Alonso-Zarazaga and Lyal 1999) but has not been documented in Peru. One species of the genus Dryophthorus Germar, 1824 and one species of the genus Stenommatus Wollaston, 1873 are recorded in South America (Wibmer and O'Brien 1986). Stenommatus with 13 recent species is distributed in Central and South America, Madagascar, Mascarene Is., Society Is., India, Japan, New Guinea and Australia (Hustache 1924; Osella 1979; Alonso-Zarazaga and Lyal 1999). Three species were described from Miocene Dominican amber (Davis and Engel 2006; Poinar and Legalov 2015). Stenommatus copalicus Poinar, Bukejs and Legalov, 2017 was described from Pleistocene Colombian copal (Poinar et al. 2017); these fossils suggest the minimum age of the genus to 15 to 20 million years ago. A key to the genus Stenommatus from New World is available (Poinar et al. 2017). The biology of Dryophthorini is poorly investigated. These Stenommatus beetles probably occur under bark of dead or dying trees (Morimoto 1978).

In this paper, I describe two new species of Stenommatus from Peru and they represent the first report of the tribe in Peru. The new species belong to the subfamily Dryophthorinae based on its geniculate antennae with a compact antennal club, first article of club elongated and other articles fused. The flagellum with 4 flagellomeres, 5-jointed tarsi, antennae inserted near the middle of rostrum, and pygidium exposed indicate placement in the tribe Dryophthorini. The eyes contiguous on the underside of the head are characteristics of the genus Stenommatus.

\section{Materials and methods}

The examined specimens are deposited at the Museo de Historia Natural, San Marcos University (Peru: Lima) - MUSM, Muséum National d' Histoire Naturelle (France: Paris) - MNHN and Institute of Systematic and Ecology of Animals (Russia: Novosibirsk) - ISEA. Description, body measuring, and photographs were performed using the Zeiss Stemi 2000-C dissecting stereomicroscope.

\section{Results \\ Descriptions of new species}

\section{Stenommatus chabooae Legalov, new species}

(Figs. 1-3, 7)

Diagnosis. The new species is similar to $S$. inflexus Hustache, 1938 (Fig. 9) from Bolivia but differs by the elytral interstria being narrower than the stria width and having a narrower pronotum. It is distinguished from $S$. sokolovi Legalov, n. sp. in the coarsely punctate pronotum; elytral interstriae narrower than stria width and a larger, narrower, weakly curved apex of aedeagus with a large basal sclerite of the endophallus.

Description. Body elongate, weakly convex dorsally, black, glabrous.

Male. Head subconical. Rostrum quite long, 3.8 times as long as wide at apex, 2.4 times as long as wide in middle, 2.8 times as long as wide at base, 0.9 times as long as pronotum, subcylindrical, curved, slightly dilated near antennal attachment, punctate. Eyes large, narrowly oval, almost flat, contiguous on underside of head. Forehead flat, punctate. Vertex densely punctate. Temples subequal to eye length. Antennae inserted laterally near middle of rostrum, geniculate. Antennomere I (scape) elongate, weakly clavate, 3.9 times as long as wide, 0.5 times as long as rostrum. Flagellum 4-articled (antennomeres II-V) short, compact. Flagellomeres subconical. Antennomere II 1.8 times as long as wide. Antennomere III equal in length and width, shorter than antennomere II. Antennomere IV 0.7 times as long as wide, shorter and wider than antennomere III. Antennomere V 0.4 times as long as wide, shorter and wider than antennomere IV. Antennal club compact, ovoid, widely rounded at apex. First segment of antennal club 1.3 times as long as wide. Second segment of antennal club 0.6 times as long as wide, 0.4 times as long as and 0.8 times as narrow as first segment of club, tomentose.

Pronotum almost bell-shaped, 1.3 times as long as wide at base, subequal to wide in middle and at base, with deep constriction in anterior fourth, without lateral carina. Anterior, posterior and lateral margins almost straight. Pronotal punctures round, dense. Distance between adjacent punctures subequal or narrower than diameter of puncture. Scutellum minute, subtriangular.

Elytra ovoid-elongate, convex, 1.6 times as long as wide at base, 1.4 times as long as wide in middle, 2.5 times as long as wide in apical fourth, 2.3 times as long as pronotum; widest before middle. Humeri smooth. Elytral punctures round, large and dense, arranged in regular striae. Elytral interstriae narrower than stria width, convex.

Precoxal portion of prosternum long, punctate. Procoxal cavities widely separated. Postcoxal portion shorter than precoxal portion. Metaventrite flattened, elongate. Metepisternum covered by elytra. Abdomen flattened, punctate. Ventrites I and II fused, subequal in length. 

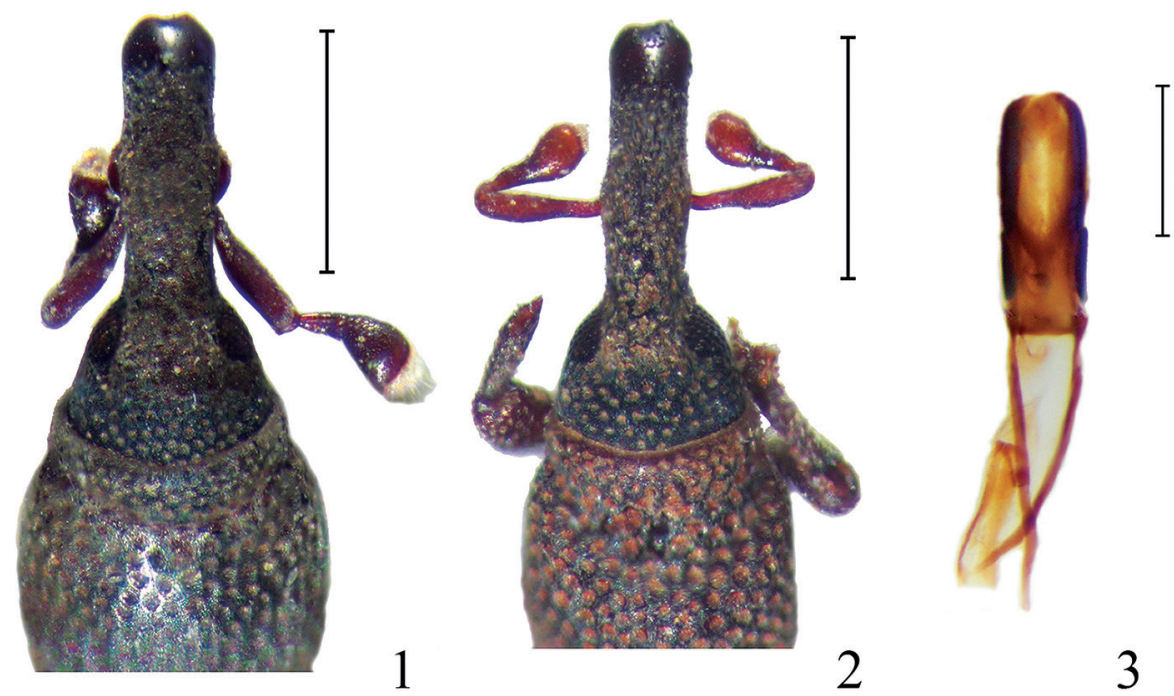

2
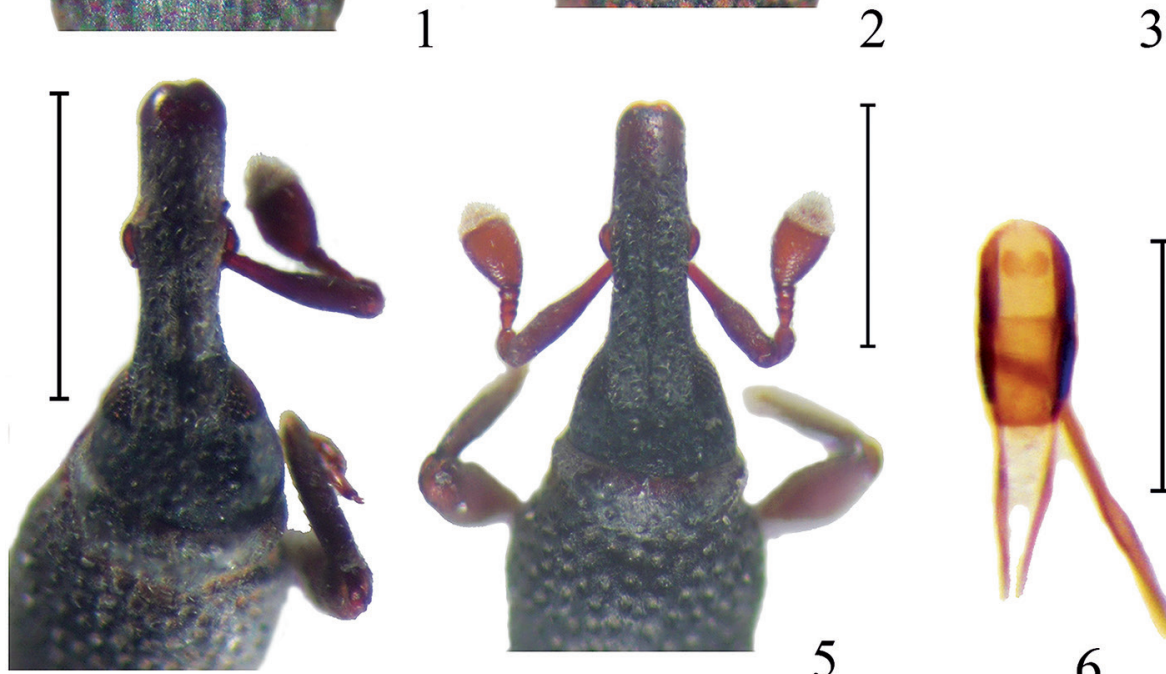

3

4

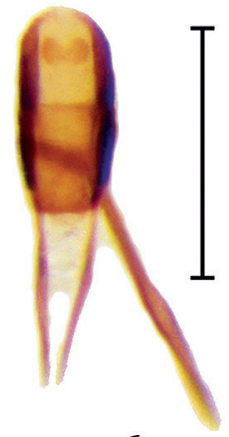

6
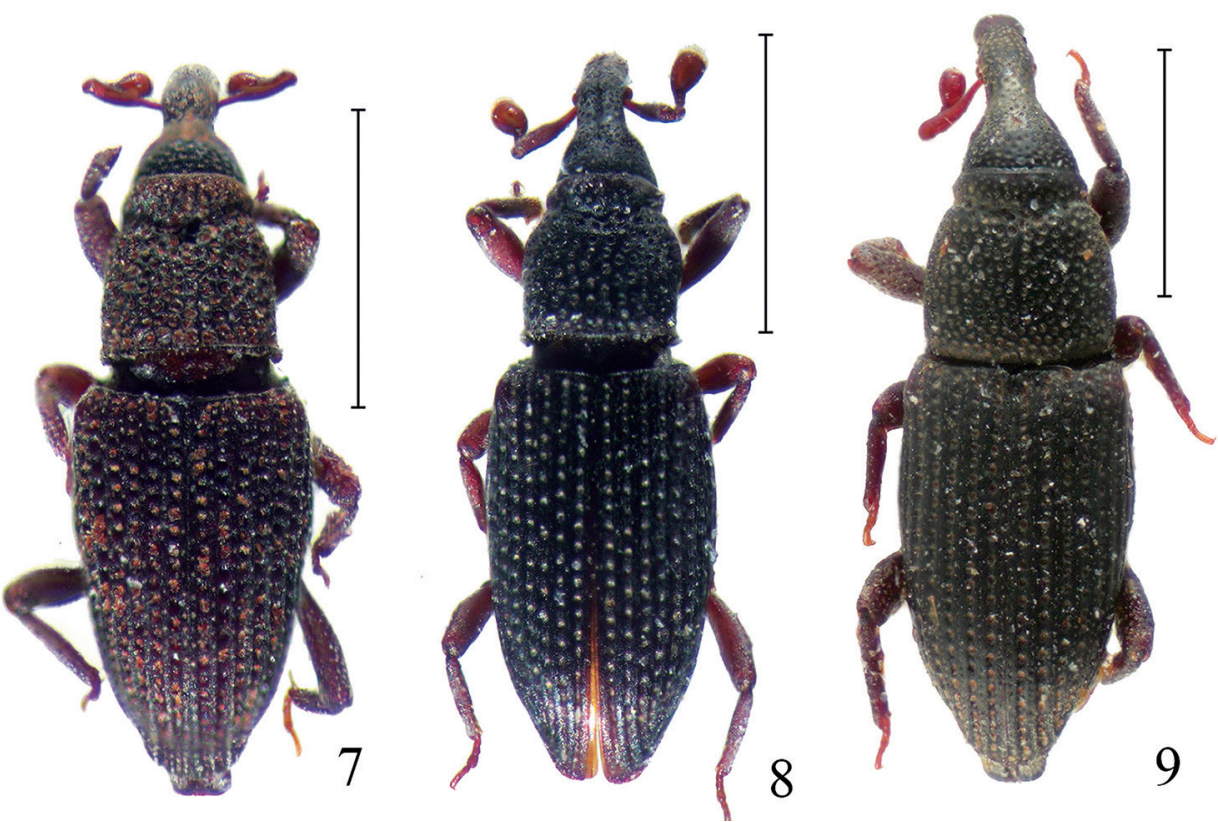

Figures 1-3. Stenommatus chabooae, male holotype and female paratype. 1) Male rostrum and head. 2) Female rostrum and head. 3) Aedeagus, dorsal view. Figures 4-6. Stenommatus sokolovi, male holotype and female paratype. 4) Male rostrum and head. 5) Female rostrum and head. 6) Aedeagus, dorsal view. 7) S. chabooae, habitus, dorsally, female paratype. 8) S. sokolovi, habitus, dorsally, female, paratype. 9) S. inflexus, habitus, dorsally, female. Scale bar: for 1, 2, 4, 5, = $0.5 \mathrm{~mm}$, for 3, $6=0.2 \mathrm{~mm}$, for 7-9 = $1.0 \mathrm{~mm}$. 
Ventrite III 0.3 times as long as ventrite II. Ventrite IV equal to ventrite III. Ventrite V 2.7 times as long as ventrite IV. Pygidium convex, sulcate, exposed.

Legs quite long. Pro- and mesocoxae spherical. Femora weakly clavate. Tibiae flattened, almost straight, with long uncus and apical groups of setae. Protibiae with mucro. Tarsi 5-jointed, slender, narrow. Tarsomeres I-IV trapezoidal. Tarsomeres I and II quite narrow. Tarsomere III slightly wider than tarsomere II, simple. Tarsomere IV small. Onychium elongate, subcylindrical. Claws small, free and simple.

Aedeagus quite large and narrow, weakly curved apex, with large basal sclerite of endophallus.

Length of body (without rostrum): $2.4 \mathrm{~mm}$. Length of rostrum: $0.6 \mathrm{~mm}$.

Female: Rostrum 3.9 times as long as wide at apex, 3.1 times as long as wide in middle and 2.9 times as long as wide at base. Pronotum 1.6 times as long as wide at apex, 1.1 times as long as wide in middle and equal to wide at base. Elytra 1.9 times as long as wide at base, 1.8 times as long as wide in middle, 3.6 times as long as wide in apical fourth, 2.2 times as long as pronotum.

Length of body (without rostrum): $1.7-2.3 \mathrm{~mm}$. Length of rostrum: $0.4-0.6 \mathrm{~mm}$.

Type material. Holotype male and one female paratype (MUSM). Type locality: PERU: Junin Dep., Satipo prov., near Rio Venado vill., $11^{\circ} 11^{\prime} 787^{\prime S}$, 7446'168"W, 1122 m, window trap, 22.IX.-18.X.2017, A. Sokolov. Paratype: 4 females (ISEA), idem.

Etymology. The species named in honour of Dr. Caroline Chaboo (USA), who organized the study of beetles from Peru.

\section{Stenommatus sokolovi Legalov, new species}

$$
\text { (Figs. 4-6, 8) }
$$

Diagnosis. The new species differs from $S$. inflexus (Fig. 9) in the elytral interstriae being as wide as the stria width, finely punctate pronotum and narrower body. It is distinguished from $S$. chabooae Legalov, n. sp. by having a finely punctate pronotum; elytral interstriae as wide as stria width; wide pronotum; narrower body; and smaller, wider, aedeagus rounded at apex without armament of the endophallus.

Description. Body elongate, weakly convex dorsally, black, glabrous.

Male. Head almost conical. Rostrum quite long, 3.8 times as long as wide at apex, 2.4 times as long as wide at base, 2.6 times as long as wide in middle, 1.7 times as long as pronotum; subcylindrical, curved, slightly dilated near antennal attachment, small and dense punctate. Eyes large, narrowly-oval, almost flat, contiguous on underside of head. Forehead flat, slightly wider than base of rostrum. Vertex convex, slightly punctate. Temples large, about 1.3 times as long as eye length. Antennae inserted laterally near middle of rostrum, geniculate, relatively short. Antennomere I (scape) large, elongate, weakly clavate, 5.0 times as long as wide, 0.6 times as long as rostrum. Flagellum (antennomeres II-V) short, compact, 4-articled. Flagellomeres subconical. Antennomere II 1.2 times as long as wide. Antennomere III shorter and narrower than antennomere II. Antennomere IV subequal to antennomere III. Antennomere $\mathrm{V}$ shorter and wider than antennomere IV. Antennal club compact, ovoid, widely rounded at apex. First segment of antennal club 1.7 times as long as wide. Second segment of antennal club 1.2 times as long as wide, 0.8 times as long as and slightly narrower than first segment of club, tomentose.

Pronotum almost bell-shaped, narrower than elytral base, 1.3 times as long as wide in middle, widest before anterior constriction, with deep constriction in anterior fourth, without lateral carina. Anterior, posterior and lateral margins almost straight. Anterior margin narrower than posterior margin. Pronotal punctures round. Distance between adjacent punctures subequal to diameter of puncture. Scutellum minute, subtriangular.

Elytra ovoid-elongate, weakly convex, 1.8 times as long as wide at base, 1.7 times as long as wide in middle, 3.2 times as long as wide in apical fourth, 2.4 times as long as pronotum; widest in basal third. Humeri smooth. Elytral punctures round, large and dense, arranged in regular striae. Elytral interstriae as wide as stria width, weakly convex.

Precoxal portion of prosternum long, punctate. Procoxal cavities widely separated. Postcoxal portion shorter than precoxal portion. Metaventrite flattened, elongate. Metepisternum covered by elytra. Abdomen flattened, punctate. Ventrites I and II fused. Ventrite II 0.7 times as long as ventrite I. Ventrite III 0.3times as long as ventrite II. Ventrite IV equal to ventrite III. Ventrite V 3.7 times as long as ventrite IV. Pygidium convex, sulcate, exposed.

Legs quite long. Pro- and mesocoxae spherical. Femora weakly clavate. Tibiae flattened, almost straight, with long uncus and apical groups of setae. Protibiae with mucro. Tarsi 5-jointed, slender, narrow. Tarsomeres I-IV trapezoidal. Tarsomeres I and II quite narrow. Tarsomere III wider than tarsomere II, simple. Tarsomere IV small. Onychium elongate, subcylindrical. Claws small, free and simple.

Length of body (without rostrum): $2.0 \mathrm{~mm}$. Length of rostrum: $0.4 \mathrm{~mm}$.

Female: Rostrum 3.7 times as long as wide at apex, 2.4 times as long as wide in middle and at base, 0.9 times as long as pronotum. Antennomere I 5.0 times as long as wide. Antennomere II 1.6 times as long as wide. Antennomere III 1.7 times as long as wide. Antennomere IV 1.3 times as long as wide. Antennomere V 0.5 times as long as wide. First segment of club 1.3 times as long as wide. Second segment of club subequal in length and width. Pronotum 1.5 times as long as wide at apex, 1.1 times as long as wide in middle and at base. Elytra 2.3 times as long as wide at base, 1.9 times as long as wide in middle, 4.0 times as long as wide in apical fourth, 2.5 times as long as pronotum. 
Aedeagus quite small and wide, rounded at apex, without armament of the endophallus.

Length of body (without rostrum): $1.2-1.3 \mathrm{~mm}$. Length of rostrum: $0.5 \mathrm{~mm}$.

Type material. Holotype male and one female paratype (MUSM). Type locality: PERU: Junin Dep., Satipo prov., near Rio Venado vill., $1^{\circ} 11^{\prime} 787^{\prime \prime S}, 74^{\circ} 46^{\prime} 168^{\prime \prime W}$, 1122 m, window trap, 13-30.XI.2016, A. Sokolov. Paratype: 1 male (ISEA), idem; 1 female (ISEA), window trap, 22.XI-18.X.2017.

Etymology. The species named in honour of Dr. Alexander V. Sokolov (Russia), who collected the specimens.

\section{Key to Species of Stenommatus from South America}

1. Elytral interstriae 2.0-2.5 times as long as stria width. Bolivia. S. inflexus Hustache, 1938

- Elytral interstriae as wide as or narrower than stria width. 2

2. Pronotum finely punctate, punctures larger and sparse. Elytral interstriae as wide as stria width.

$$
\text { S. sokolovi Legalov, new species }
$$

Pronotum coarsely punctate, punctures smaller and dense. Elytral interstriae narrower than stria width.

$$
\text { S. chabooae Legalov, new species }
$$

\section{Literature cited}

Alonso-Zarazaga M.A. \& C.H.C. Lyal. 1999. A world catalogue of families and genera Curculionoidea (Insecta: Coleoptera) (excepting Scolytidae and Platypodidae). Barcelona, Entomopraxis, 316 p.

Anderson R.S. \& A.E. Marvaldi. 2014. 3.7.3. Dryophthorinae Schoenherr, 1825. In: Leschen RAB \& RG Beutel (eds.). Handbook of Zoology. Arthropoda: Insecta. Tb. 40: Coleoptera (Beetles). Volume 3: Morphology and Systematics (Phytophaga). De Gruyter, Berlin and Boston: $477-482$

Chaboo C.S. 2015. Beetles (Coleoptera) of Peru: A survey of the families. Part I. Overview. Journal of the Kansas Entomological Society 88 (2): 135-139. https://doi. org/10.2317/0022-8567-88.2.135
Davis S.R. \& M.S. Engel. 2006. Dryophthorine weevils in Dominican amber (Coleoptera: Curculionidae). Transactions of the Kansas Academy of Science 109: 191-198. https://doi.org/10.1660/00228443(2006)109[191:DWIDAC]2.0.CO;2

Erichson G.F. 1847. Conspectus insectorum coleopterum, quae in Republica Peruana observata sunt. Archiv für Naturgeschichte 13: 67-185.

Howden A.T. 2001. A new species of Pandeleteius from Peru. Revue Francaise d' Entomologie 23 (2): 171-175.

Hustache A. 1924. Synopsis des Curculionides de Madagascar. Bulletin de l'Académie Malgache 7: 1-545.

Hustache A. 1929. Nouveaux Curculionides de l'Amérique du Sud. Revista de la Sociedad Entomológica Argentina 2: 227-232.

Kirsch T. 1874. Beitrage zur Kenntniss der Peruanischen Kaferfauna auf Dr. Abendroth's Sammlungen basirt. Berliner Entomologische Zeitschrift 18 (3-4): 385-432.

Morimoto K. 1978. Check-list of the family Rhynchophoridae (Coleoptera) of Japan, with descriptions of a new genus and five new species. Esakia 12: 103-118.

Osella G. 1979. Nuove specie di Curculionidi delle isole Mascaregne (Coleoptera). Revue Suisse de Zoologie 86 (1): $37-48$.

Poinar G.Jr. \& A.A. Legalov. 2015. New species of the genera Dryophthorus Germ. and Stenommatus Woll. (Coleoptera: Dryophthoridae: Dryophthoridae) in Dominican amber. Historical Biology 27 (5): 508-513. https:// doi.org/10.1080/08912963.2014.892938

Poinar G.Jr., A. Bukejs \& A.A. Legalov. 2017. First records of weevils (Coleoptera: Curculionidae) in Quaternary Colombian copal. Revista Colombiana de Entomología 43 (1): 85-90. https://doi.org/10.25100/socolen. v43i1.6654

Voss E. 1954. Curculionidae (Col.). Beitrage zur Fauna Perus 4. Jena: 13-364.

Wibmer G.J. \& C.W. O'Brien. 1986. Annotated checklist of the weevils (Curculionidae sensu lato) of South America (Coleoptera: Curculionoidea). Memoirs of the American Entomological Institute 39: i-xvi, 1-563.
Acknowledgements:

I am grateful to Alexander G. Kirejtshuk (Russia: Saint-Petersburg; France: Paris), Hélène Perrin (France: Paris), and Alexander V. Sokolov (Russia: Moscow). I also thank Caroline Chaboo (USA: Lincoln) for motivating the study and commenting on an early draft and three reviewers for their valuable suggestions that improved the manuscript.

Competing interests:

Author have declared that no competing interests exist.

Funding:

The author received no specific funding for this work.

Ethics / legal statement :

Biological material proceeded from museum collections and specific permission not was required. 
